Кривобочек Виталий Григорьевич, $\partial-p$ c.- $x$. наук, проф., главный научный сотрудник, Пензенский научно-исследовательский институт сельского хозяйства. Россия.

442731, Пензенская обл., р.п. Лунино, ул. Мичурина, 16.

Тел.: 89042668573; e-mail:penzniish-szk@mail.ri.

Стаценко Александр Петрович, $\partial-p$ c.- $x$. наук, проф. кафедры «Техносферная безопасность», Пензенский государственный университет. Россия.

Тразанова Екатерина Александровна, аспирант кафедры «Техносферная безопасность», Пензен- ский государственный университет. Россия.

Курышев Иван Александрович, аспирант кафедры «Техносферная безопасность», Пензенский государственный университет. Россия.

440028, г. Пенза, ул. Красная, 40.

Тел.: (8412) 36-82-93.

Ключевые слова: культурные растения; солеустойчивость; аминокислота пролин; коэффициент солеустойчивости; группы устойчивости; сорта-дифференцииаторы; селекционный материал.

\title{
FREE PROLINE - BIOCHEMICAL INDICATOR OF PLANTS SALT TOLERANCE
}

Krivobochek Vitaliy Grigoryevich, Doctor of Agricultural Sciences, Professor, Head of the chair "Selection of Sereals", Penza Scientific Research Institute of Agriculture. Russia.

Statsenko Alexander Petrovich, Doctor of Agricultural Sciences, Professor of the chair "Technosphere safety". Penza State Universuty. Russia.

Trazanova Ekaterina Alexandovna, Post-graduate Student of the chair "Technosphere safety", Penza State University. Russia.

Kuryshev Ivan Alexandrovich, Post-graduate Student of the chair "Technosphere safety", Penza State University. Russia.
Keywords: cultivated plants; salinization; the amino acid proline; the ratio of salt; group sustainability; varieties differentiators; breeding material.

A close affinity between containing of free proline in vegetative organs and salinization resistance of cultivated plants has been revealed, whereby agricultural plants resistance criterion to soil salinization has been set. Salinization resistance of 16 cultivared plants has been assessed. As a result the plants have been devided into 3 salinization resistant groups: highly resistant to salinty stress (sunflower, barley, rye, triticale, fall wheat), medium resistant (rice, buckwheat, sorghum, oat, millet, maize) and weakly resistant (lupine, bean, kidney beans, peas, soybean).

\section{БИОХИМИЧЕСКОЕ И БАКТЕРИАЛЬНОЕ СОСТОЯНИЕ МОЛОКА У ЛАКТИРУЮЩИХ КОРОВ ПРИ РАЗЛИЧНЫХ ФОРМАХ ЭНДОМЕТРИТА}

ЛЯШЕНКО Надежда Юрьевна, Саратовский государственный аграрный университет имени Н.И. Вавилова

ФИЛАТОВА Алена Владимировна, Саратовский государственный аграрный университет имени Н.И. Вавилова

АВДЕЕНКО Владимир Семенович, Саратовский государственный аграрный университет имени Н.И. Вавилова

Рассмотрены физико-химические свойства молока коров при различных формах эндометрита. Установлено, что у коров, больных эндометритом, в течение лактации наблюдается выраженная положительная корреляция между числом соматических клеток (СК) и концентрацией в молоке лактоферрина и умеренная отрицательная корреляиия между содержанием лактопероксидазы и активностью каталазы. Число мезофильных анаэробных лактатсбраживающих микроорганизмов зависит от уровня общей бактериальной обсемененности молока и состояния половых органов $(p<0,05)$. У коров, больных острым эндометритом, общая бактериальная обсемененность в 2 раза выше, чем у клинически здоровых.

$\mathrm{M}$ одернизация молочного скотоводства как отрасли имеет большое социально-экономическое значение с точки зрения обеспечения населения биологичес- ки полноценными продуктами питания [8]. В настоящее время одна из актуальных проблем - производство качественного молока и готовых молочных продуктов, гарантирую- 
щих полную безопасность при их потреблении $[2,4]$. В связи с этим большое внимание должно уделяться здоровью животных. Секрет вымени коров подвергается значительным изменениям при воспалениях половых органов $[1,13,14]$.

Среди биохимических методов исследования молока особое значение отводится активности ферментов [3, 6]. Для определения качественных показателей прежде всего обращают внимание на такие из них, как каталаза, редуктаза и лизоцим [5, 7]. Однако ферментная активность молока коров при различных формах эндометрита практически не изучена $[9,10]$. В то же время изменения активности ферментов в молочной железе больных животных часто настолько чувствительны, что нередко обнаруживаются еще до появления клинических признаков заболевания и могут повлиять на качество молочного продукта $[11,12]$.

Цель данной работы - проведение ветеринарно-санитарной оценки информативных биохимических параметров молока при различных формах эндометрита у коров для определения его качества.

Методика исследований. Экспериментальные исследования проводили в 20132016 гг. в хозяйствах Саратовской области (ЗАО Племзавод «Трудовое», учебно-опытное хозяйство РГАУ-МСХА им. К.А. Тимирязева ФГУП «Муммовское»). Всего под наблюдением находилось 1450 коров. В ходе работы проводили клинические исследования животных и лабораторную оценку молока, полученного от коров, больных различными формами эндометрита.

Ветеринарно-санитарную экспертизу молока осуществляли по результатам клинического обследования коров и лабораторного исследования секрета (реакция секрета с тестами: «Кетотест», «Масттест», 2\%-м раствором мастидина, 5\%-м раствором димастина; проба отстаивания). Для гематологических исследований кровь брали перед утренним кормлением. Биохимические исследования крови проводили на анализаторе CIBACORING 288 BLOOD GAS SYSCEM (СШA).

Для оценки секрета вымени определяли пероксидазную активность (ЛПО) по Б.П. Плешкову (1976) и выражали в у.ед., концентрацию лактоферрина (ЛФ) - с помощью радиальной иммунодиффузии по
G.A. Manhcini (1965) в модификации Б.Е. Караваева (1983), свободный оксипролин спектрофотометрически по М.А. Осадчуку (1979) в модификации Т.П. Кузнецовой и др. (1982) и выражали в процентах оптической плотности (\%оп).

Статистическую обработку полученных данных проводили с помощью компьютерной программы Statistica 5.0.

Результаты исследований. Результаты лабораторных анализов секрета вымени у коров при заболевании эндометритом различного генеза представлены в табл. 1.

Анализ полученных материалов свидетельствует о том, что общей закономерностью изменений, происходящих в молоке, полученном от больных эндометритом коров, по сравнению с здоровыми является снижение активности мурамидазы. Следовательно, у лактирующих коров при заболевании эндометритом в молочной железе проявляется активация клеточной защиты и фактора неспецифической локальной резистентности лактоферрина. Характер функционального состояния молочной железы предопределяет особенности лактопероксидазной активности секрета. Результаты лабораторных анализов секрета вымени клинически здоровых коров и больных эндометритом различного генеза представлены в табл. 2.

Анализ полученных материалов свидетельствует о том, что в молоке при эндометритах повышается количество соматических клеток $(p<0,01)$, лактоферрина $(p<0,01)$ и снижается активность каталазы $(p<0,01)$ и свободного оксипролина $(p<0,05)$. Значительное поступление соматических клеток в молочную железу из кровяного русла обусловлено достаточным количеством фагоцитов, что способствует защите здоровья вымени. Поскольку фагоцитарная активность поступивших в пораженный орган кровеносных клеток значительно снижается по сравнению с клинически здоровыми животными, то клеточная защита начинает работать по экстенсивному типу.

Нейтрофилы и лактоциты, являясь источником лактоферрина в секрете вымени, высвобождают его из специальных гранул за счет дегрануляции первых во время фагоцитоза и разрушения этих гранул, что обусловливает его высокую концентрацию при воспалительных процессах в матке больных 


\section{Биохимические показатели секрета молочной железы у коров при различных формах эндометрита}

\begin{tabular}{|l|c|c|c|}
\hline \multirow{2}{*}{\multicolumn{1}{|c|}{ Показатели }} & \multicolumn{3}{|c|}{ Эндометрит } \\
\cline { 2 - 4 } & $\begin{array}{c}\text { острый } \\
(n=35)\end{array}$ & $\begin{array}{c}\text { подострый } \\
(n=20)\end{array}$ & $\begin{array}{c}\text { хронический } \\
(n=12)\end{array}$ \\
\hline Общий белок, \% & $3,19 \pm 0,13$ & $3,23 \pm 0,18$ & $3,04 \pm 0,14$ \\
\hline Альбумины, \% & $14,9 \pm 0,13$ & $17,0 \pm 0,12^{* *}$ & $15,3 \pm 0,17$ \\
\hline$\alpha$-лактоальбумин, \% & $15,2 \pm 0,20$ & $14,9 \pm 0,43$ & $13,2 \pm 0,23$ \\
\hline$\beta$-лактоглобулин, \% & $66,0 \pm 0,25$ & $45,3 \pm 0,32^{* *}$ & $49,7 \pm 0,41^{* *}$ \\
\hline$\gamma$-лактоглобулин, \% & $3,9 \pm 0,19$ & $6,6 \pm 0,24^{* *}$ & $2,8 \pm 0,42$ \\
\hline & \multicolumn{4}{|c|}{ Иммуноглобулины, мг/мл } & $2,55 \pm 0,13$ \\
\hline G & $2,74 \pm 0,08$ & $4,78 \pm 0,09^{* *}$ & $0,22 \pm 0,02$ \\
\hline M & $0,31 \pm 0,03$ & $0,17 \pm 0,03^{*}$ & $0,49 \pm 0,04$ \\
\hline Мурамидаза, у. ед. & $0,59 \pm 0,02$ & $0,40 \pm 0,09^{*}$ & \\
\hline
\end{tabular}

${ }^{*} p<0,05 ;{ }^{*} p<0,01$ (здесь и далее).

Таблица 2

Показатели секрета молочной железы у коров при различных формах эндометрита

\begin{tabular}{|l|c|c|c|c|}
\hline \multirow{2}{*}{\multicolumn{1}{|c|}{ Показатели }} & \begin{tabular}{c} 
Клинически \\
здоровые \\
\cline { 3 - 5 }
\end{tabular} & $\begin{array}{c}\text { острый } \\
(n=35)\end{array}$ & $\begin{array}{c}\text { Подострый } \\
(n=12)\end{array}$ & $\begin{array}{c}\text { хронический } \\
(n=17)\end{array}$ \\
\hline Соматические клетки, тыс./мл & $270 \pm 15,12$ & $1763,3 \pm 217,1^{* *}$ & $3599 \pm 57^{* *}$ & $6505 \pm 19^{* *}$ \\
\hline Оксипролин свободный, \%оп & $5,78 \pm 0,7$ & $4,45 \pm 0,72$ & $3,72 \pm 0,6^{*}$ & $3,22 \pm 0,21^{*}$ \\
\hline Лактопероксидаза, у. ед. & $650,7 \pm 42,1$ & $887,2 \pm 72,6^{*}$ & $992 \pm 47^{*}$ & $1211 \pm 15^{* *}$ \\
\hline Лактоферрин, мкг/мл & $139,4 \pm 3,56$ & $300,0 \pm 56,7^{* *}$ & $359 \pm 62^{* *}$ & $489 \pm 84^{* *}$ \\
\hline Активность каталазы, с & $350,5 \pm 42,7$ & $6,87 \pm 0,42^{* *}$ & $6,57 \pm 0,6^{* *}$ & $5,92 \pm 0,6^{* *}$ \\
\hline
\end{tabular}

коров. В молоке коров при эндометритах изменяется содержание лактопероксидазы. Активность ее возрастает в несколько десятков раз при хронических формах эндометрита $(p<0,01)$.

Стабилизация лактогенеза при заболевании матки обусловливает необходимость регулярного опорожнения вымени и притока из крови свежих нейтрофилов, участвующих в фагоцитозе микроорганизмов и выделяющих интенсивно фермент в секрет, о чем свидетельствует повышение его активности при подостром и хроническом эндометрите. Кроме того, дополнительное поступление лактопероксидазы в молоко происходит при деструкции лактоцитов. Следовательно, у лактирующих коров при эндометрите в молочной железе происходит активация клеточной защиты вымени от болезнетворных агентов и фактора неспецифической локальной резистентности лактоферрина. Характер функционального состояния молочной 
железы предопределяет особенности лактопероксидазной активности секрета $(p<0,01)$. Полученные данные статистически достоверны.

Установлено, что у коров при эндометрите секрет вымени подвергается достоверным изменениям, с высокой степенью корреляции. Так, количество соматических клеток возрастает в сотни и тысячи раз при острой форме эндометрита $-r=0,572, p<0,001$; при подострой форме $-r=0,863, p<0,01$, а при хронической $-r=0,958, p<0,05$. Так, активность лактопероксидазы и концентрация лактоферрина в 1,42 раза увеличиваются при остром эндометрите, в 2,52 раза при подостром и возвращаются к исходному уровню у коров, больных хронической формой эндометрита.

Таким образом, полученные результаты позволяют по информативным показателям секрета молочной железы вести контроль течения воспалительного процесса в матке и эффективно лечить коров, больных различными формами эндометрита (табл. 3). Исследования показали, что при различных формах эндометрита у коров происходят определенные изменения секрета вымени.

Деструкция лактогенной ткани при воспалительных заболеваниях репродуктивных органов у высокопродуктивных коров способствует высвобождению биологически активных веществ, обеспечивающих высокий уровень локальной неспецифической резистентности.
Анализ корреляционных связей между показателями неспецифической резистентности у животных при заболевании эндометритом в течение лактации показал выраженную положительную корреляцию между числом соматических клеток (СК) и концентрацией в молоке ЛФ и средней степени отрицательную корреляцию между содержанием ЛПО и активностью каталазы.

Для микробиологического исследования проводили отбор проб молока от коров, больных эндометритом, в период лактации (табл. 4). Результаты исследований свидетельствуют о том, что число мезофильных анаэробных лактатсбраживающих микроорганизмов зависит от уровня общей бактериальной обсемененности молока и состояния половых органов $(p<0,05)$. Так, у коров, больных острым эндометритом, общая бактериальная обсемененность в 2 раза выше, чем у клинически здоровых. При хроническом эндометрите общая бактериальная обсемененность составила $287,9 \pm 19,5$ тыс. $/$ см $^{3}$, что в высокой степени статистически достоверно $(p<0,01)$.

Из проб молока коров чаще всего выделяли C. sporogenes, C. butyricum, а также C. tyrobutyricum и C. tertium, т. е. во всех случаях преобладали психотрофные (до 76,0%) микроорганизмы (табл. 5).

По данным микробиологических исследований, в молоке коров при остром эндометрите общая бактериальная обсемененность мезофильными микроорганизмами

Таблица 3

Физико-химические параметры молока коров, больных эндометритом

\begin{tabular}{|c|c|c|c|c|}
\hline \multirow{2}{*}{ Показатель } & \multicolumn{3}{|c|}{ Эндометрит } & \multirow{2}{*}{$\begin{array}{c}\text { Клинически } \\
\text { здоровые } \\
(n=35)\end{array}$} \\
\hline & $\begin{array}{l}\text { острый } \\
(n=20)\end{array}$ & $\begin{array}{c}\text { подострый } \\
\quad(n=12)\end{array}$ & $\begin{array}{c}\text { хронический } \\
(n=17)\end{array}$ & \\
\hline Кислотность, ${ }^{\circ} \mathrm{T}$ & $18,30 \pm 0,12$ & $19,00 \pm 0,09 *$ & $18,40 \pm 0,13$ & $16,80 \pm 0,11^{*}$ \\
\hline Плотность, кг/м³ & $1030,6 \pm 12,6$ & $1032,7 \pm 11,2$ & $1031,9 \pm 10,8$ & $1028,7 \pm 10,9$ \\
\hline Жир, \% & $3,97 \pm 0,09$ & $3808 \pm 0,06$ & $3,92 \pm 0,04$ & $4,14 \pm 0,05$ \\
\hline COMO, \% & $8,91 \pm 0,04$ & $8,42 \pm 0,03^{*}$ & $8,86 \pm 0,07$ & $8,37 \pm 0,03^{*}$ \\
\hline Казеин, \% & $2,63 \pm 0,04$ & $2,64 \pm 0,03^{*}$ & $2,71 \pm 0,06$ & $2,82 \pm 0,05$ \\
\hline Лактоза, \% & $4,44 \pm 0,06$ & $4,38 \pm 0,07$ & $4,45 \pm 0,03$ & $4,61 \pm 0,07^{*}$ \\
\hline $\begin{array}{l}\text { Сычужная свертывае- } \\
\text { мость, мин }\end{array}$ & $45,8 \pm 2,54$ & $45,5 \pm 1,19^{*}$ & $47,0 \pm 2,17$ & $40,3 \pm 3,43^{*}$ \\
\hline
\end{tabular}


Микробиологические параметры молока коров, больных эндометритом

\begin{tabular}{|c|c|c|c|}
\hline \multirow[b]{2}{*}{ Показатель } & \multicolumn{3}{|c|}{ Эндометрит } \\
\hline & $\begin{array}{l}\text { острый } \\
(n=20)\end{array}$ & $\begin{array}{l}\text { подострый } \\
(n=12)\end{array}$ & $\begin{array}{l}\text { хронический } \\
(n=17)\end{array}$ \\
\hline $\begin{array}{l}\text { Контаминация микроорганизмами, } \\
\text { тыс. } / \text { см }^{3}\end{array}$ & $478,9 \pm 22,8^{* *}$ & $345,9 \pm 21,2^{*}$ & $287,9 \pm 19,5^{* *}$ \\
\hline КМАФнМ, КОЕ $/ \mathrm{cM}^{3}$ & $(5,1 \pm 0,12) \cdot 10^{4^{* *}}$ & $(4,8 \pm 0,09) \cdot 10^{4^{*}}$ & $(4,2 \pm 0,09) \cdot 10^{4^{*}}$ \\
\hline $\begin{array}{l}\text { Количество патогенных микроорга- } \\
\text { низмов, в } 25 \text { см }^{3}\end{array}$ & - & - & - \\
\hline $\begin{array}{l}\text { Количество мезофильных анаэроб- } \\
\text { ных микроорганизмов, м.к. /см³ }\end{array}$ & $112,7 \pm 12,8^{* *}$ & $88,9 \pm 10,38$ & $72,6 \pm 10,9 * *$ \\
\hline
\end{tabular}

Таблица 5

Групповой состав микроорганизмов в молоке коров

\begin{tabular}{|l|c|c|c|}
\hline \multirow{2}{*}{ Микроорганизмы } & \multicolumn{2}{|c|}{ Эндометрит } \\
\cline { 2 - 4 } & $\begin{array}{c}\text { острый } \\
(n=20)\end{array}$ & $\begin{array}{c}\text { подострый } \\
(n=12)\end{array}$ & $\begin{array}{c}\text { хронический } \\
(n=17)\end{array}$ \\
\hline Термостойкие & $0,87 \pm 0,09$ & $0,77 \pm 0,05^{* *}$ & $309,6 \pm 21,3^{* *}$ \\
\hline Мезофильные & $425,5 \pm 56,7$ & $325,5 \pm 36,2^{* *}$ & $30,9 \pm 3,21^{* *}$ \\
\hline Психотрофные & $45,7 \pm 4,65$ & $34,7 \pm 2,25^{*}$ & 3 \\
\hline
\end{tabular}

составляла на 1 -е сутки 345,9 тыс. $/ \mathrm{cm}^{3}$, что соответствует $88,63 \%$ от общего количества выделенных бактерий (см. табл. 4). Психотрофные микроорганизмы составляют $11,26 \%$ от общего количества, а термостойкие 0,11 \% (см. табл. 5).

Таким образом, полученные результаты позволяют по информативным показателям секрета молочной железы вести контроль течения воспалительного процесса в половых органах коров и эффективности лечения различных форм эндометрита.

Выводы. Содержание свободного оксипролина в секрете вымени коров при эндометрите возрастает в 1,92 раза по сравнению с клинически здоровыми животными.

В результате анализа корреляционных связей между показателями неспецифической резистентности молочной железы установлено, что у коров, больных эндо- метритом, в течение лактации наблюдается выраженная положительная корреляция между числом соматических клеток и концентрацией в молоке лактоферрина и умеренная отрицательная корреляция между содержанием лактопероксидазы и активностью каталазы.

Число мезофильных анаэробных лактатсбраживающих микроорганизмов зависит от уровня общей бактериальной обсемененности молока и состояния половых органов $(p<0,05)$. У коров, больных острым эндометритом, общая бактериальная обсемененность в 2 раза выше, чем у клинически здоровых.

\section{СПИСОК ЛИТЕРАТУРЫ}

1. Авдеенко В.С., Ливерко И.В. Особенности иммунологических изменений клинически здоровых лактирующих коров при физиологической перестройке молочной железы // Материа- 
лы Междунар. науч. конф., посвящ. 125-летию академии. - Казань, 1999. - С. 15-18.

2. Авдеенко В.С., Авдеенко А.В., Родин Н.В. Ферментный состав молока у коров при различном функциональном состоянии молочной железы // Аграрная наука в XXI веке: проблемы и перспективы; ФГБОУ ВПО «Саратовский государственный аграрный университет им. Н.И. Вавилова». - Саратов, 2013. - С. 112-113.

3. Авдеенко В.С., Ляшенко С.Н., Советкин С.В. Совершенствование способов лечения послеродовых эндометритов у коров // Ветеринарный врач. - 2009. - № 4. - С. 50-52.

4. Багманов М.А. Патология молочной железы у домашних животных. - Казань, 2011. - 229 с.

5. Дегтярева С.С. Острый послеродовой эндометрит бактериально-микозной этиологии у коров и его фармакотерапия: автореф. дис. ... канд. вет. наук. - Краснодар, 2008. - 27 с.

6. Новикова Е.Н. Фармако-профилактика острых послеродовых эндометритов у коров: автореф. дис. ... канд. вет. наук. - Краснодар, 2013. -27 c.

7. Перспектива решения акушерско-гинекологической патологии у коров на промышленной ферме / И.С. Коба [и др.] // Труды Кубанского государственного аграрного университета. - 2012. - 1(34). - С. 194-196.

8. Слободяник В.И., Париков В.А., Подберезный B.B. Иммунологические аспекты физиологии и патологии молочной железы коров. - Таганрог, 2009. - 375 с.

9. Этиология, диагностика и оценка молока при функциональных нарушениях молочной железы у коров / В.С. Авдеенко [и др.] // Аграрный научный журнал. - 2013. - № 10. C. 27-29.

10. Chauhan, Surinder S. Antioxidant dynamics in the live animal and implications for ruminant health and product (meat/milk) quality: role of vitamin $\mathrm{E}$ and selenium // Animal Production Science August, 2014, 54(10), P. 1525-1536.

11. Lucey $S$. Short-term associations between disease and milk yield of dairy cows // Journal of Dairy Research / Volume 53 / Issue 01 / February 1986, Pages 7-15.

12. Potter, Timothy J. Risk factors for clinical endometritis in postpartum dairy cattle, 2010, Vol. 74, P. 127-134.

13. Rowlands G.J., LuceyS. Changes in milk yield in dairy cows associated with metabolic and reproductive disease and lameness // Preventive Veterinary Medicine, 1986, Vol. 4, P. 205-221.

14. Rowlands G.J., Lucey S., Russell A.M. Susceptibility to disease in the dairy cow and its relationship with occurrences of other diseases in the current of preceding lactation, 1986, Vol. 4, P. $223-234$.

Ляшенко Надежда Юрьевна, аспирант кафедры «Болезни животных и ветеринарно-санитарная экспертиза», Саратовский государственный аграрный университет имени Н.И. Вавилова. Россия.

Филатова Алена Владимировна, канд. биол. наук, доцент кафедры «Болезни животных и ветеринарно-санитарная экспертиза», Саратовский государственный аграрный университет имени Н.И. Вавилова. Россия.

Авдеенко Владимир Семенович, $\partial-p$ вет. наук, проф. кафедры «Болезни животных и ветеринарно-санитарная экспертиза», Саратовский государственный аграрный университет имени Н.И. Вавилова. Россия.

410005, г. Саратов, ул. Соколовая, 335.

Тел.: (8452) 69-25-32.

Ключевые слова: лактирующие коровы; эндометрит; молоко; молочная железа; ветеринарно-санитарная экспертиза.

\section{BIOCHEMICAL AND BACTERIAL STATE OF MILK IN LACTATING COWS IN VARIOUS FORMS OF ENDOMETRITIS}

Lyashenko Nadezhda Yuryevna, Post-graduate Student of the chair "Animals' diseases and Veterinariansanitarian Expertise", Saratov State Agrarian University named after N.I. Vavilov. Russia.

Philatova Alena Vladimirovna, Candidate of Biological Sciences, Associate Professor of the chair "Animals' diseases and Veterinarian-sanitarian Expertise", Saratov State Agrarian University named after N.I. Vavilov. Russia.

Avdeenko Vladimir Semenovich, Doctor of Veterinary Sciences, Professor of the chair "Animals' diseases and Veterinarian-sanitarian Expertise", Saratov State Agrarian University named after N.I. Vavilov. Russia.

Keywords: lactating cows; endometritis; milk; mammary gland; veterinarian-sanitarian expertise.
They are regarded physicochemical properties of milk of cows with different forms of endometritis. It was found out that cows with endometritis during lactation there is a strong positive correlation between the number of somatic cells (SC) and lactoferrin concentration in the milk, as well as moderate negative correlation between lactoperoxidase content and catalase activity. The number of mesophilic anaerobic lactate fermenting microorganisms depends on the level of total bacterial contamination of milk and the state of the genital organs $(p<0.05)$. In cows with acute endometritis, the total bacterial contamination 2 times higher than in clinically healthy ones. 